\title{
The Chronically Reserpinized Rat as a Possible Model for Cystic Fibrosis. II. Composition and Cilioinhibitory Effects of Submaxillary Saliva
}

\author{
J. RICARDO MARTINEZ, (45) PATRICIA C. ADSHEAD, DAVID O. QUISSELL, AND GIULIO J. BARBERO \\ Department of Child Health and Pulmonary Division, Department of Medicine, University of Missouri, \\ School of Medicine, Columbia, Missouri, USA
}

Extract

Submaxillary saliva was obtained from rats treated for 7 days with a daily dose of $0.5 \mathrm{mg} / \mathrm{kg}$ reserpine and from untreated controls. Secretory (volume) response, total protein, total carbohydrate, and $\mathrm{Na}^{+}$and $\mathrm{Ca}^{++}$concentrations were compared. After pilocarpine stimulation, saliva from treated animals showed significantly elevated concentrations of $\mathrm{Na}^{+}$, $\mathrm{Ca}^{++}$, total protein, and total carbohydrate. Total volume output was only $20 \%$ and maximum flow rate was $50 \%$ of those in control animals. A single injection of guanethidine (2 $\mathrm{mg} / \mathrm{kg}$ ) $30 \mathrm{~min}$ before stimulation increased the volume output and resulted in normal protein concentrations in saliva from reserpinized animals. Treatment of the animals with isoproterenol $(5 \mathrm{mg} / \mathrm{kg}$ daily) for 7 days after three doses of reserpine also partially restored the volume response to pilocarpine, but resulted in higher protein outputs. The reverse treatment (isoproterenol followed by reserpine) did not change the volume output but resulted in even higher ratios of secreted protein per unit of gland weight. Stimulation of salivary secretion with isoproterenol resulted in very high protein concentrations and in a markedly increased total protein output in reserpinized animals. Both pilocarpine and isoproterenol-stimulated saliva from reserpinized rats showed ciliostatic effects when added to gills of fresh water mussels. Such effects were similar to those produced by serum from patients with cystic fibrosis.

Since a decreased secretory response and elevated concentrations of $\mathrm{Na}^{+}, \mathrm{Ca}^{+}$, protein, and carbohydrate have been found in submaxillary saliva of cystic fibrosis (CF) patients, the results obtained in these experiments suggest that the reserpinized rat may provide a potential animal model for studying the pathogenesis of the disease. This view is further supported by the demonstration of cilioinhibitory properties in the saliva of treated animals, which are similar to those of CF serum.

\section{Speculation}

Treatment of rats with reserpine for 7 days results in elevations of $\mathrm{Na}^{+}, \mathrm{Ca}^{++}$, protein, and carbohydrate concentrations in submaxillary saliva secreted after a pilocarpine stimulus. These findings are similar to those reported in submaxillary saliva from $\mathrm{CF}$ patients after parasympathomimetic stimulation and suggest a possible model for the study of the secretory abnormality in the disease. The demonstration of ciliotoxic properties in saliva from the treated animals, which closely resemble those of CF serum, lends support to the concept of an animal model.
The secretory abnormality in cystic fibrosis is generally described as the production of thick, viscous fluids that precipitate and cause obstruction in the secretory units of exocrine glands $(9-11)$. The chemical abnormality that may be responsible for the disturbed physicochemical behavior of exocrine secretions is a matter of debate. Changes in the fucose or sialic acid end groups or in the sulfated components of glycoproteins have been described $(12,19)$. Others believe that there is abnormal binding of glycoproteins to calcium ions, with a change in the solubility of these complex molecules $(6,7,17)$. Because of the inconsistency of results, however, some investigators have suggested that the mucoprotein abnormality in CF may be a quantitative one, with larger amounts of a normal secretory product being produced which overwhelm the secretory capacity of the cells (30). Regardless of the nature of the mucoprotein abnormality, there is general agreement that submaxillary secretions in $\mathrm{CF}$ show elevations in total protein, carbohydrate, and certain electrolytes, primarily $\mathrm{Na}^{+}, \mathrm{Cl}^{2}$, and $\mathrm{Ca}^{+}(6,7,21)$.

In recent years, the secretory abnormality in $\mathrm{CF}$ has been further characterized by the discovery of a factor or factors in the serum, saliva, and sweat from cystic fibrosis patients that inhibit ciliary activity in both invertebrate $(3,4,13)$ and vertebrate (31) tissues and also $\mathrm{Na}^{+}$reabsorption in the rat parotid gland $(22,23)$. The demonstration of structural changes in the submaxillary gland of reserpine-treated rats which resemble those observed in $\mathrm{CF}$, suggests that the study of salivary secretions in the treated animals could be of interest in further elucidating the drug-induced exocrinopathy. In this investigation, therefore, submaxillary saliva was collected from reserpinized rats and its composition compared with that of stimulated saliva from untreated controls. In addition, its effects on the ciliary activity of gills from fresh water mussels were compared with those of control saliva and of serum from CF patients.

\section{MATERIALS AND METHODS}

The observations to be reported refer to animals treated with $0.5 \mathrm{mg} / \mathrm{kg} / 24 \mathrm{hr}$ reserpine (35), inasmuch as the morphologic study showed that they had developed typical structural changes in the gland. The animals were treated for a period of 7 days and had access to water and standard laboratory chow. Twenty-four hours after the last injection of the drug, the rats were anesthetized by intraperitoneal injections of sodium pentobarbital $(6 \mathrm{mg} / 100 \mathrm{~g}$ body weight) and the submaxillary glands on one or both sides were dissected. The main excretory ducts were cannulated with 
small lengths of polyethylene tubing (36), approximately 0.8 $\mathrm{cm}$ distal to the hilum. The ductal cannulas had a tip diameter of approximately $150 \mu \mathrm{m}$, obtained by pulling the polyethylene over a microflame. As spontaneous or resting secretion of saliva does not occur from the submaxillary gland of the rat, salivary flow was stimulated by intraperitoneal injections of pilocarpine nitrate $(1 \mathrm{mg} / 100 \mathrm{~g}$ body weight) or $d l$-isoproterenol hydrochloride $(10 \mathrm{mg} / \mathrm{rat})$. Both drugs were obtained from Sigma Chemical Co. (37), and were freshly dissolved in distilled water or in isotonic saline. Two to $3 \mathrm{~min}$ after the injection of the secretagogue, salivary flow began. Saliva secreted in the first $4 \mathrm{~min}$ was discarded, but subsequent secretion was collected in preweighed plastic microsample tubes. Collection periods were timed to collect at least $50 \mu 1$ fluid for analysis. At the end of the collection period, the cannulas were removed, and the glands were surgically extracted, blotted in tissue paper, and weighed to the nearest milligram. The tubes containing the collected samples were reweighed and flow rates were expressed as microliters per minute per gram wet weight. Collected samples were analyzed for $\mathrm{Na}^{+}$and $\mathrm{K}^{+}$in an IL flame photometer (38) with lithium as internal standard. Total protein was determined colorimetrically according to the method of Lowry (20). $\mathrm{Ca}^{H+}$ concentrations were determined in a calcium analyzer (39) and total carbohydrate by the method of Dubois et al. (15). The same procedures for collection and analysis were carried out in submaxillary saliva from untreated controls after each type of stimulation.

In some animals, a single injection of guanethidine $(2 \mathrm{mg} / \mathrm{kg}$ body weight) (40) was given intraperitoneally $30 \mathrm{~min}$ before stimulation with pilocarpine. After stimulation with the secretagogue, salivary samples were collected and analyzed as described before.

Since chronic treatment with the $\beta$-adrenergic drug, isoproterenol, has been reported to result in structural and functional changes in the salivary glands of rodents $(14,16$, $24,27,33$ ), this drug was given to some animals in combination with reserpine. In six animals, isoproterenol (5 $\mathrm{mg} / \mathrm{kg}$ daily) was injected intraperitoneally for 3 days and then reserpine was given in daily doses of $0.5 \mathrm{mg} / \mathrm{kg}$ for 7 days. In six other animals, the opposite schedule of treatment was employed. In either case, the first drug was given for 4 additional days after treatment with the second drug had begun. Twenty-four hours after the last dose, the rats were anesthetized and submaxillary saliva was collected and analyzed as described above after a pilocarpine stimulus.

Distal gill filaments of the fresh water mussel Unio (41) were dissected and placed on a double concavity slide containing tap water. They were exposed to $1: 1$ mixtures of stimulated saliva and tap water and constantly observed under a Zeiss-Wild inverted microscope with a green filter. Changes in the activity and morphology of terminal cilia were timed and recorded. Other gill filaments were exposed to stimulated saliva from control rats or to serum from CF patients, from parents of CF patients, and from control subjects. According to the data of Spock (32), ciliary assays are positive in $75-80 \%$ of CF patients and can detect CF heterozygotes with only $65-70 \%$ accuracy.

\section{RESULTS}

\section{COMPOSITION OF SALIVA}

Effects of Reserpine Treatment. When compared with saliva from control animals, submaxillary saliva secreted after stimulation with pilocarpine from reserpinized rats showed elevated concentrations of $\mathrm{Na}^{+}$(Fig. 1), Ca ${ }^{++}$(Fig. 2), total protein (Fig. 3), and total carbohydrate (Fig. 4).

The elevated concentrations of electrolytes and organic components were particularly marked at low flow rates. In the case of $\mathrm{Na}^{+}$, concentration values overlapped with normal ones at flow rates above $20-25 \mu \mathrm{l} / \mathrm{min} \mathrm{g}$ wet weight. Calcium,

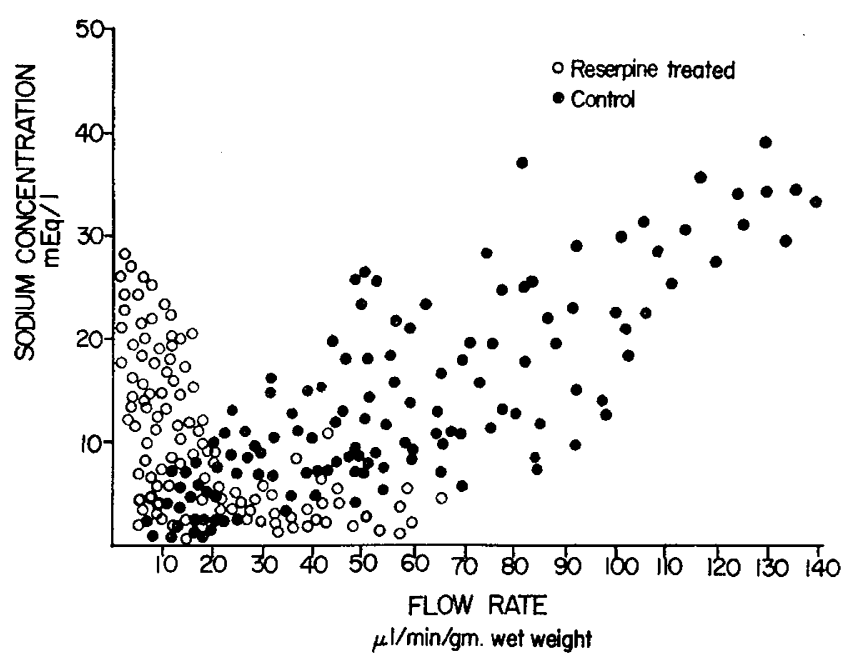

Fig. 1. Sodium concentration as a function of flow rate in submaxillary saliva from control $(\bullet)$ and reserpine-treated rats ( $($ ) after pilocarpine stimulation.

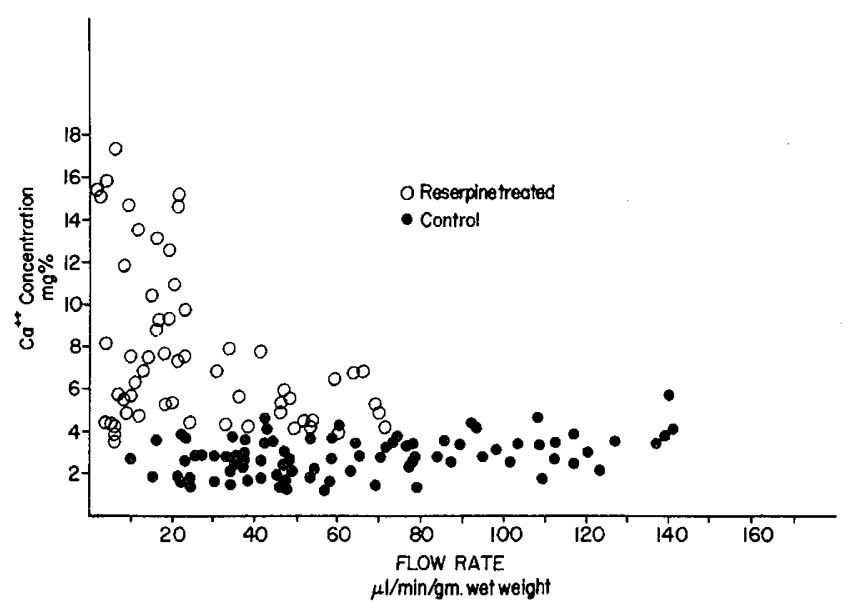

Fig. 2. Calcium concentration as a function of flow rate in submaxillary saliva from control $(\bullet)$ and reserpine-treated rats $(0)$ after stimulation with pilocarpine.

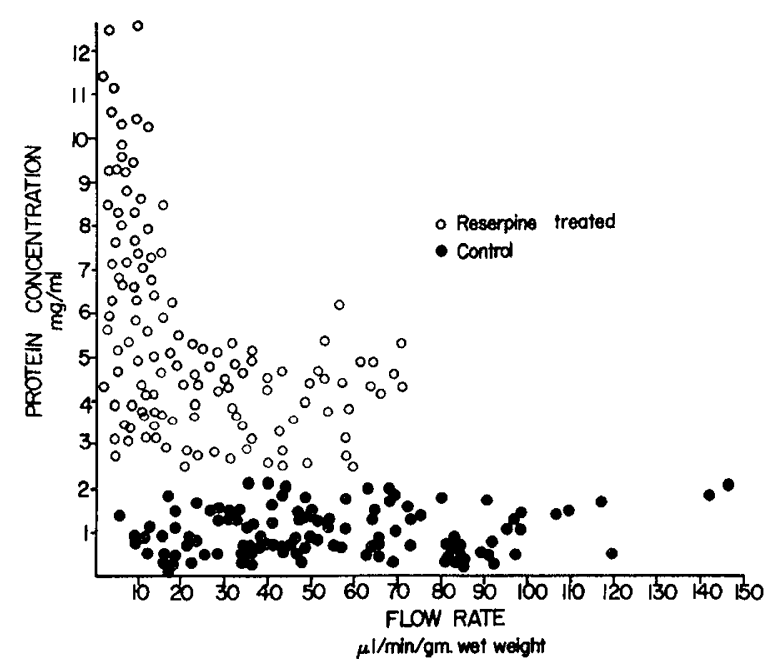

Fig. 3. Protein concentration as a function of flow rate in submaxillary saliva from control $(\bullet)$ and reserpinized animals $(0)$ after pilocarpine stimulation.

carbohydrate, and protein concentrations were elevated at all flow rates, but the elevation was particularly evident at low rates of salivary flow.

The total volume output from the glands of experimental 
animals was markedly reduced when compared with that from control glands (Table 1). The reduced secretory response was also demonstrated by a maximum flow rate which was $50 \%$ of normal as shown in Figures $1-4$ and in Table 1. Despite the reduced water output, however, the total amount of protein secreted by reserpinized animals was significantly higher than that of untreated controls. This is particularly evident when the amount of protein secreted is expressed as a function of gland weight.

Stimulation with the $\beta$-adrenergic agonist isoproterenol resulted in total volume outputs slightly lower and in maximum flow rates not significantly different from those of untreated controls (Table 1). Protein concentrations were, however, markedly elevated in the saliva from the experimental animal (Fig. 5) and total protein output was also significantly higher (Table 1). Salivary samples had a cloudy appearance and some developed a white precipitate upon standing.

Effects of Combined Drug Treatments. A single injection of guanethidine $0.5 \mathrm{hr}$ before stimulation with pilocarpine increased the volume output threefold (Table 1), and resulted

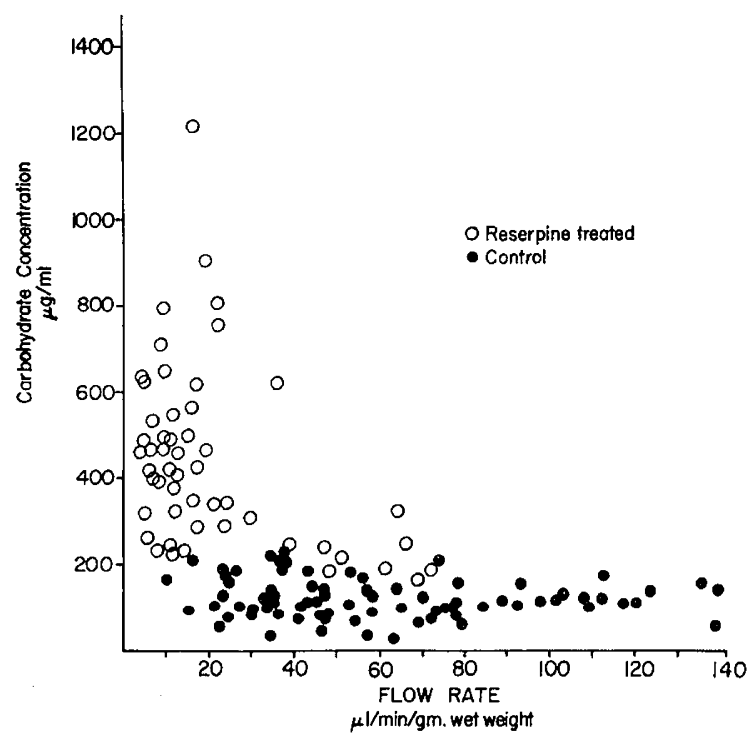

Fig. 4. Carbohydrate concentration as a function of flow rate in submaxillary|saliva from control $(\bullet)$ and reserpinized animals $(0)$ after stimulation with pilocarpine. in a total protein output similar to that of untreated controls. The protein concentration in individual saliva samples was, therefore, within normal limits.

Treatment with isoproterenol for 7 days after reserpine had been given for 3 days also partially restored the volume response (Table 1). Total protein output, however, was even higher than in rats treated with reserpine alone. The reverse treatment, isoproterenol followed by reserpine, resulted in volume outputs similar to those of rats treated with reserpine alone and in higher ratios of secreted protein to gland weight (Table 1). The total protein secreted by these animals was, however, lower than that observed in animals treated with reserpine followed by isoproterenol.

Ciliary Assay. Saliva from reserpinized rats obtained after a pilocarpine stimulus caused a gradual slowing, asynchrony, and dyskinesia of the terminal cilia from the distal gills of Unio. Accompanying this effect there was a concomitant thickening and curling of the cilia and ejection of cellular material. The cilia appeared to be trapped by disrupted cytoplasm and cellular debris accumulated on the surface of the gill. These effects occurred from 10-45 min after exposure of the gill to the saliva. By contrast, saliva from the experimental animals obtained after an isoproterenol stimulus produced a rapid

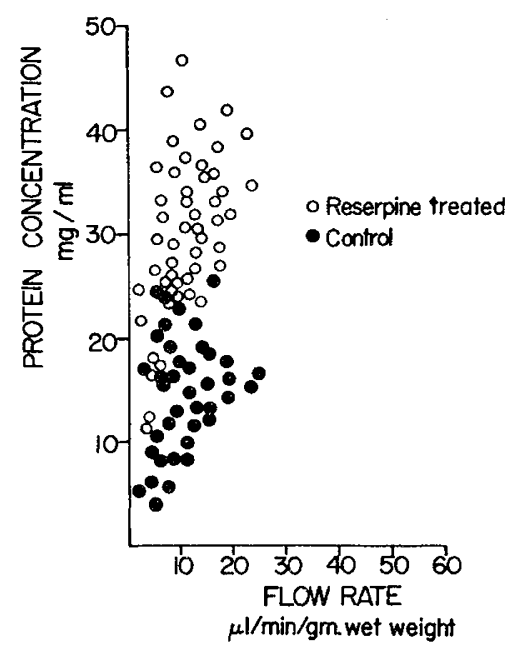

Fig. 5. Protein concentration as a function of flow rate in submaxillary saliva from control $(\bullet)$ and reserpine-treated rats $(0)$ after stimulation with isoproterenol.

Table 1. Secretory (volume) response and protein output from submaxillary gland and effects of guanethidine injection and isoproterenol treatment ${ }^{1}$

\begin{tabular}{|c|c|c|c|c|c|c|}
\hline Treatment & $\mathrm{n}^{2}$ & $\begin{array}{l}\text { Maximum } \\
\text { flow rate, } \\
\mu 1 / \mathrm{min} / \mathrm{g}\end{array}$ & $\begin{array}{l}\text { Total volume } \\
\text { secreted, } \mu \mathrm{l}\end{array}$ & $\begin{array}{c}\text { Volume secreted } \\
\text { per gland weight, } \\
\mu \mathrm{l} / \mathrm{mg}\end{array}$ & $\begin{array}{l}\text { Total protein } \\
\text { secreted, } \mu \mathrm{g}\end{array}$ & $\begin{array}{l}\text { Protein secreted } \\
\text { per gland weight, } \\
\mu \mathrm{g} / \mathrm{mg}\end{array}$ \\
\hline $\begin{array}{l}\text { Control, pilocarpine } \\
\text { stimulation }\end{array}$ & 18 & 146 & $\begin{array}{l}1,924.4 \\
( \pm 161.3)\end{array}$ & $\begin{array}{c}7.56 \\
( \pm 0.88)\end{array}$ & $\begin{array}{l}1,494.3 \\
( \pm 124.4)\end{array}$ & $\begin{array}{c}5.8 \\
( \pm 0.3)\end{array}$ \\
\hline $\begin{array}{l}\text { Reserpine, pilocarpine } \\
\text { stimulation }\end{array}$ & 18 & 72 & $\begin{array}{c}314.6 \\
( \pm 29.3)\end{array}$ & $\begin{array}{c}1.54 \\
( \pm 0.12)\end{array}$ & $\begin{array}{l}2,031.8 \\
( \pm 201.4)\end{array}$ & $\begin{array}{l}10.75 \\
( \pm 1.14)\end{array}$ \\
\hline $\begin{array}{l}\text { Control, isoproterenol } \\
\text { stimulation }\end{array}$ & 12 & 34 & $\begin{array}{c}166.8 \\
( \pm 14.2)\end{array}$ & $\begin{array}{c}0.93 \\
( \pm 0.12)\end{array}$ & $\begin{array}{l}2,839.8 \\
( \pm 201.4)\end{array}$ & $\begin{array}{c}15.80 \\
( \pm 1.00)\end{array}$ \\
\hline $\begin{array}{l}\text { Reserpine, isoproterenol } \\
\text { stimulation }\end{array}$ & 18 & 30 & $\begin{array}{c}163.9 \\
( \pm 14.5)\end{array}$ & $\begin{array}{c}0.82 \\
( \pm 0.06)\end{array}$ & $\begin{array}{l}4,096.5 \\
( \pm 461.2)\end{array}$ & $\begin{array}{l}25.88 \\
( \pm 2.46)\end{array}$ \\
\hline $\begin{array}{l}\text { Reserpine, guanethidine } \\
\text { injection }\end{array}$ & 6 & 56 & $\begin{array}{c}978.0 \\
( \pm 32.1)\end{array}$ & $\begin{array}{c}4.29 \\
( \pm 0.31)\end{array}$ & $\begin{array}{l}1,159.6 \\
( \pm 62.4)\end{array}$ & $\begin{array}{c}5.09 \\
( \pm 0.29)\end{array}$ \\
\hline Reserpine-isoproterenol & 6 & 58 & $\begin{array}{c}1,081.8 \\
( \pm 63.8)\end{array}$ & $\begin{array}{c}4.04 \\
( \pm 0.27)\end{array}$ & $\begin{array}{l}3,377.0 \\
( \pm 474.8)\end{array}$ & $\begin{array}{c}12.59 \\
( \pm 1.30)\end{array}$ \\
\hline Isoproterenol-reserpine & 6 & 33 & $\begin{array}{l}369.7 \\
( \pm 63.3)\end{array}$ & $\begin{array}{c}2.06 \\
( \pm 63.3)\end{array}$ & $\begin{array}{l}2,492.3 \\
( \pm 545.9)\end{array}$ & $\begin{array}{c}13.54 \\
( \pm 2.60)\end{array}$ \\
\hline
\end{tabular}

${ }_{1}^{1}$ Figures in parenthesis indicate \pm from the mean SD.

${ }^{2} \mathrm{n}=$ number of animals. 
Table 2. Cilioinhibitory effects of submaxillary saliva

\begin{tabular}{|c|c|c|c|c|}
\hline Treatment & Stimulation & $\begin{array}{l}\text { Protein concentration } \\
\text { in saliva samples, } \mathrm{mg} / \mathrm{ml}\end{array}$ & $\begin{array}{l}\text { Time required for } \\
\text { ciliary inhibition, } \\
\text { min }\end{array}$ & $\begin{array}{l}\text { Characteristics of } \\
\text { ciliary inhibition }\end{array}$ \\
\hline Control & Pilocarpine & $0.2-2.0$ & $>60$ & $\begin{array}{l}\text { No behavioral or } \\
\text { morphologic changes }\end{array}$ \\
\hline Reserpine & Pilocarpine & $4.0-12.0$ & $10-45$ & $\begin{array}{l}\text { Slowing, asynchrony, } \\
\text { dyskinesia, thickening } \\
\text { and curling of cilia }\end{array}$ \\
\hline Reserpine & Isoproterenol & $15.0-50.0$ & $2-8$ & Cessation of beat \\
\hline
\end{tabular}

cessation of ciliary beat $(2-8 \mathrm{~min})$ without obvious changes in the appearance of the cilia. Saliva from untreated controls, on the other hand, did not cause any change in ciliary behavior or morphology after more than $1 \mathrm{hr}$ of exposure. Table 2 shows these behavioral and morphologic alterations, together with data on the protein concentration of the salivary fluids.

The same two types of responses, the gradual inhibition of ciliary beat and the shock-stopped reaction, were observed when the cilia were treated with diluted serum from CF patients or from their parents. By contrast, serum from normal subjects produced a rapid cessation of ciliary activity (in $3-8$ $\min$ ) followed by a rapid recovery and continued activity for more than $60 \mathrm{~min}$. Serum from treated rats was tested in only four experiments. Two samples caused a cessation of beat in 11 and $15 \mathrm{~min}$, respectively, and two other caused a slow inhibition of activity, asynchrony, mounding, and ejection of debris. The latter effect was maximal after 12 and $20 \mathrm{~min}$ of exposure of the cilia to the serum. In the present experiments, the assay was reproducible for the different test fluids used, and no differences were discernible between the effects of serum from CF patients and from their parents.

\section{DISCUSSION}

The elevated concentrations of $\mathrm{Na}^{+}, \mathrm{Ca}^{+}$, protein, and carbohydrate observed in submaxillary saliva from reserpinetreated rats after pilocarpine stimulation represent a functional derangement that is similar to that reported in the same secretion from patients with cystic fibrosis $(6,7,21)$. Although some investigators have reported sodium concentrations to be elevated but not significantly different from normal (6), more recent studies, based on a larger series of patients, have demonstrated clearly that the composition of submaxillary saliva is markedly altered in CF patients (21). Documented alterations include significant elevations in $\mathrm{Na}^{+}$, $\mathrm{Cl}^{-}, \mathrm{Ca}^{++}$, organic nonelectrolytes (urea, uric acid), and protein. At present, there is general agreement that these changes are found consistently in CF patients, particularly in regard to total protein $(9-11)$. With regard to the carbohydrate content of submaxillary saliva from cystic fibrosis patients, Chernick and Barbero (7) found elevated concentrations of fucose and hexosamine, and Mandel et al. (21) reported elevated concentrations of carbohydrate. It appears justified, therefore, to regard the observed alterations in the composition of submaxillary saliva from reserpinized rats as reflecting a secretory disturbance that resembles that observed in submaxillary glands of CF patients.

Furthermore, secretory (volume) responses from the submaxillary gland of CF patients have been described as either essentially normal or slightly lower than in normal individuals (9-11). However, in a study of both reflex and parasympathomimetically stimulated saliva, Chernick and Barbero (7) found a significant decrease in submaxillary salivary flow (milliliters per minute) in CF patients. The mean value for the control group was 0.92 and that for the cystic fibrosis group, 0.56 . Secretory response in human salivary glands is generally expressed as volume flow (milliliters per minute or per hour) and not as flow rate (milliliters per minute per gram wet weight) or as total output. Despite this difference, however, the above mentioned study clearly indicates a decreased secretory response in CF patients. The same alteration has been found in our experimental model. It may be useful to re-evaluate the secretory response in cystic fibrosis patients in terms of total volume output.

Isoproterenol was used in combination with reserpine in view of its demonstrated sialadenotrophic effects $(14,16,26$, 27,33 ). These effects could be additive to those produced by reserpine and result in a more pronounced sialadenopathy than that produced by either drug alone. A single injection of guanethidine before stimulation with the secretagogue was tried in view of the reversal it has been shown to produce both in the appearance and protein concentration of CF submaxillary saliva (8). Both the chronic treatment with isoproterenol and the acute injection of guanethidine partially restore the volume response from the gland of treated animals. This suggests that the decreased secretory response to pilocarpine in the treated animals is a reversible phenomenon. It is not possible at present to identify the mechanism underlying this partial restoration of the secretory (volume) response. Chronic treatment with isoproterenol resulted, however, in higher protein output in stimulated saliva than that observed in animals treated with reserpine alone, whereas a guanethidine injection before stimulation actually reduced protein excretion to normal levels. The enhanced protein excretion observed when isoproterenol was given in combination with reserpine probably results from the stimulation of protein synthesis caused by the former drug (16). The guanethidine effect is more difficult to explain with evidence presently available. Guanethidine also depletes catecholamines from adrenergic tissues, although it does so through a different mechanism than reserpine $(5,29)$. Further experiments are necessary to elucidate this reversal phenomenon caused by guanethidine. It is quite possible, however, that, in addition to the depletion of catecholamines (2), reserpine also effects the secretory cells directly, as it does in other target tissues $(18,28,34)$. The guanethidine reversal of the reserpine effect is particularly interesting in view of the fact that it has been described in cystic fibrosis patients. Chernick and Barbero (8) reported that a single injection of guanethidine before stimulation reverted the elevated protein concentrations of CF submaxillary saliva. It is attractive to speculate that in both the reserpine-treated rat and in the CF patient there is a similar biochemical abnormality which guanethidine corrects through some as yet unknown mechanism.

The extremely high protein concentrations observed in saliva from experimental animals after stimulation with isoproterenol support the view that the material that accumulates in the gland after chronic administration of reserpine (see previous paper) is secretory material. Furthermore, the cloudy appearance of this saliva is of interest since the same phenomenon has been described in saliva from patients with cystic fibrosis (7). The formation of precipitates in these samples may be relevant, if it also occurs in vivo, in explaining the histologic picture of duct obstruction. Although 
at different concentration levels, saliva from reserpinized animals has a higher protein content than the respective controls after either pilocarpine of isoproterenol stimulation: the protein concentration seems to be relevant to other observations besides the possible formation of intraductal precipitates. Both types of salivas from the experimental animal were shown to have ciliotoxic effects when added to gill preparations from fresh water mussels. This effect differs, however, depending on the type of stimulation used to elicit salivary secretion, and could be related to the protein concentration of the saliva (see Table 2), although other factors such as osmolarity or specific ion concentrations of the salivary secretions could be important in the production of specific ciliotoxic effects. One possibility that may be relevant to the concept of an animal model is the presence of a specific ciliotoxic factor or factors in the saliva from the treated animals. Such factors have been suspected in saliva (13) and in serum $(3,4,31)$ from cystic fibrosis patients. It is not possible at this time to establish whether a similar factor or factors are present in the human and animal fluids, but the absence of cilioinhibitory action in saliva from untreated animals would suggest that reserpine induces biochemical changes in the submaxillary gland that result in the appearance of either an abnormal component or elevated levels of a normal component in the saliva that possess the ciliotoxic properties. As a possible correlation, we have observed that the behavioral changes in the cilia caused by saliva from the experimental animal stimulated with either pilocarpine or isoproterenol are not isolated or independent phenomena. As reported elsewhere, both types of responses are underlined by marked alterations in the morphology and ultrastructure of both cilia and adjacent cell structures (1).

The combination of histochemical evidence of mucoprotein accumulation (see previous article), and the secretory abnormalities herein described strongly suggest the potential use of the reserpine-treated rat as a model for the study of the exocrine gland abnormality in CF. The drug-induced exocrinopathy we have obtained is similar, by the indices studied so far, to that which has been described in submaxillary glands of patients with CF. Other studies have indicated that treatment with reserpine also induces morphologic changes in other exocrine glands (25). At the present time, this animal model appears to be a useful tool in the study of the pathogenesis of $\mathrm{CF}$. Induction by a drug of a sialadenopathy resembling that of the human disease should permit a more thorough analysis of the abnormal secretory process in $\mathrm{CF}$ and, furthermore, provide an experimental method for screening possible pharmacologic approaches to its correction or improvement.

\section{SUMMARY}

Submaxillary saliva from reserpine-treated rats was found to have alterations in composition similar to those reported in the same secretion from patients with cystic fibrosis. Changes included elevated concentrations of $\mathrm{Na}^{+}, \mathrm{Ca}^{+}$, protein, and carbohydrate. In addition, this saliva was found to have ciliotoxic properties similar to those of CF serum. The similarities in cilioinhibitory effects, salivary composition, and histologic appearance justify the use of the chronically reserpinized rat as a model for cystic fibrosis.

\section{REFERENCES AND NOTES}

1. Adshead, P. C., Martinez, J. R., Kilburn, K. H., and Hess, R. A.: Ciliary inhibition and microtubule alteration in fresh-water mussels. (To be published. Proceedings of the Conference on the Biology of Cytoplasmic Microtubules, New York Academy of Sciences, New York, May 1974).

2. Benmiloud, M., and von Euler, U. S.: Effects of bretyllium, reserpine, guanethidine and sympathetic denervation on the nonadrenaline content of the rat submaxillary gland. Acta Physiol. Scand., 59: 34 (1963).

3. Besley, G. T., Patrick, A. D., and Norman, A. P.: Inhibition of the motility of gill cilia of Dreissensia by plasma of cystic fibrosis patients and their parents. J. Med. Genet., 6: 278 (1969).

4. Bowman, B. H., Lockhart, L. H., and McCombs, M. L.: Oyster ciliary inhibition by cystic fibrosis factor. Science, 164: 235 (1969).

5. Carlson, A.: Pharmacological depletion of catecholamine stores. Pharmacol. Rev., 18: 541 (1966).

6. Chernick, W. S., and Barbero, G. J.: Studies on submaxillary saliva in cystic fibrosis. J. Pediat., 59: 890 (1961).

7. Chernick, W. S., and Barbero G. J.: Studies on human tracheobronchial and submaxillary secretions in normal and pathophysiological conditions. Ann. N. Y. Acad. Sci., 106: 698 (1963).

8. Chernick, W. S., and Barbero, G. J.: Reversal of submaxillary saliva alterations in cystic fibrosis by guanethidine. Mod. Prob. Pediat., 10: 125 (1967)

9. Di Sant'Agnese, P. A., and Talamo, R. C.: Pathogenesis and physiopathology of cystic fibrosis of the pancreas. New Engl. J. Med., 277: 1287 (1967).

10. Di Sant'Agnese, P. A., and Talamo, R. C.: Pathogenesis and physiopathology of cystic fibrosis of the pancreas. New Engl. J. Med., 277: 1343 (1967).

11. Di Sant'Agnese, P. A., and Talamo, R. C.: Pathogenesis and physiopathology of cystic fibrosis of the pancreas. New Engl. J. Med., 277: 1399 (1967).

12. Dische, Z., Di Sant'Agnese, P. A., Pallavicini, C., and Youlos, J.: Composition of mucoprotein fractions from duodenal fluid of patients with cystic fibrosis and controls. Pediatrics, 24: 74 (1959)

13. Doggett, R. G., and Harrison, G. M.: Cystic fibrosis: In vitro reversal of the ciliostatic character of serum and salivary secretions by heparin. Nature, 243: 251 (1973)

14. Dreisbach, R. H.: Effect of isoproterenol on calcium, protein and electrolytes of rat submaxillary gland. Proc. Soc. Exp. Biol. Med., 126: 279 (1967).

15. Dubois, M., Gilles, K. A., Hamilton, J. D., Rebers, P. A., and Smith, F.: Colorimetric method for determination of sugars and related substances. Anal. Chem., 28: 350 (1956).

16. Ekfors, T., and Barka, T.: The effect of isoproterenol on protein synthesis in rat submandibular gland. Lab. Invest., 24: 197 (1971).

17. Gugler, E., Pallavincini, J. C., Swerdlow, H., and di Sant'Agnese, P. A.: Role of calcium in submaxillary saliva of patients with cystic fibrosis. J. Pediat., 71: 585 (1967).

18. Iwayama, T., Fleming, W. W., and Burnstock, G.: Ultrastructure of mitrochondria in atrial muscle associated with depression and supersensitivity produced by reserpine. J. Pharmacol. Exp. Ther., 184: 95 (1973).

19. Johansen, P. G.: Some observations on mucous secretions in cystic fibrosis of the pancreas. Ann. N. Y. Acad. Sci., 106: 755 (1963).

20. Lowry, O. H., Rosebrough, N. F., Farr, A. L., and Randall, R. J.: Protein measurement with the Folin phenol reagent. J. Biol. Chem., 193: 265 (1951).

21. Mandel, J. D., Kutscher, A., Denning, C. R., Thompson, R. H., and Zegarelli, E. V.: Salivary studies in cystic fibrosis. Amer. J. Dis. Child., 113: 431 (1967).

22. Mangos, J. A., and McSherry, N. R.: Sodium transport inhibiryry factor in sweat of patients with cystic fibrosis. Science, 158:134 (1967).

23. Mangos, J. A., McSherry, N. R., and Benke, P. J.: A sodium transport inhibitory factor in the saliva of patients with cystic fibrosis of the pancreas. Pediat. Res., $1: 436$ (1967).

24. Mangos, J. A., McSherry, N. R., Benke, P. J., and Spock, A.: Studies on the pathogenesis of cystic fibrosis: The isoproterenol treated rat as an experimental model. In: D. Lawson: Proceedings of the Fifth International Cystic Fibrosis Conference, pp. 25-34 Cambridge, England, 1969 (Cystic Fibrosis Trust, London, 1969).

25. Martinez, J. R., and Immken, $\bar{L} .:$ Comparison of exocrine giand histochemistry in patients with cystic fibrosis and rats treated with reserpine (in preparation).

26. Menaker, L., Sheetz, J. H., Cobb, C. M., and Navia, J. M.: Gel electrophoresis of whole saliva and associated histologic changes in submandibular glands of isoproterenol-treated rats. Lab. Invest., 24: 197 (1971).

27. Schneyer, C. A.: Salivary gland changes after isoproterenol induced enlargement. Amer. J. Physiol., 203: 232 (1962).

28. Schwartz, A., and Lee, K. S.: Effect of reserpine on heart mitochondria. Nature, 188: 948 (1960).

29. Shore, P. A.: Transport and storage of biogenic amines. Pharmacol. Rev., 22: 209 (1972).

30. Spicer, S. S.: Histochemical methods for mucosubstances and their application in normal and pathologic states. In: P. A. di Sant'Agnese: Research on Pathogenesis of Cystic Fibrosis, p. 26 (Bernesaa, Ma., Iyoo).

31. Spock, A., Heick, E. M. C., Cress, H., Logan, W. S.: Abnormal serum factor in patients with cystic fibrosis of the pancreas. Pediat. Res., 1: 173 (1967).

32. Spock, A.: Ciliary inhibitor factor of cystic fibrosis. GAP 
Conference Report, National Cystic Fibrosis Research Foundation, Galveston, Texas, October, 1973.

33. Takahama, M., and Barka, T.: Electron microscopic alterations of submaxillary gland produced by isoproterenol. J. Ultrastruct. Res., 17: 452 (1967).

34. Wilcken, D. E. L., Brender, D., Shorey, C. D., and MacDonald, G. J.: Reserpine: Effect on structure of heart muscle. Science, 157: 1332 (1967).

35. Reserpine, Vitarine Co., New York, N. Y.

36. Clay Adams PE 10, Clay Adams, A Division of Beeton, Dickinson Co., Parsippony, N. J.

37. St. Louis, Mo.

38. Instrumentation Laboratories, Lexington, Mass.

39. Corning Scientific Instruments, Medfield, Mass.

Copyright (c) 1975 International Pediatric Research Foundation, Inc.
40. Ismelin, Ciba Pharmaceutical Co., Summit, N. J.

41. Obtained from Carolina Supply Co., Burlington, N. C.

42. The authors wish to express their appreciation to Mr. Douglas Wood for this help in treating the animals and in performing experiments.

43. Dr. J. R. Martinez was recipient of a Research Scholar Award from the National Cystic Fibrosis Research Foundation.

44. This research was supported by a grant from the National Cystic Fibrosis Research Foundation, Atlanta, Georgia.

45. Requests for reprints should be addressed to: J. R. Martinez, M.D., Department of Child Health, University of Missouri Medical Center, N712 Medical Sciences Building, Columbia, Mo. 65201 (USA).

46. Accepted for publication November 20, 1974.

Printed in U.S.A.

Pediat. Res. 9: 475-480 (1975)

Arylsulfatase B

lysosomal disorders
Maroteaux-Lamy syndrome mucopolysaccharidosis

\title{
Arylsulfatase B Deficiency in Maroteaux-Lamy Syndrome: Cellular Studies and Carrier Identification
}

\author{
NICHOLAS G. BERATIS, (36) BRYAN M. TURNER, ROBERTA WEISS, AND KURT HIRSCHHORN \\ Division of Medical Genetics, Department of Pediatrics, Mount Sinai School of Medicine of the City University of \\ New York, New York, New York, USA
}

\section{Extract}

Arylsulfatase B activity was studied in peripheral leukocytes obtained from 11 normal subjects, 2 obligate heterozygotes for Maroteaux-Lamy syndrome (MLS), and 1 homozygote for MLS. The activity (mean $\pm \mathrm{SD}$ ) was $113.7 \pm 36.2$ (range 57.4-181.8), 31.0 (25.7-34.5), and $5.0 \mathrm{nmol}$ 4-nitrocatechol $/ \mathrm{mg}$ protein $/ \mathrm{hr}$, respectively. Although overlap occurred on two occasions between adjacent groups on single enzyme determinations, no overlap was observed between normal subjects, heterozygotes, and the homozygote when the mean activities of replicate assays performed were considered. In two normal siblings of the patient, sibling $l$ and sibling 2, the activity was $\mathbf{5 0 . 1}$ and $\mathbf{1 0 6 . 3}$, respectively. Arylsulfatase $B$ activity in cultured skin fibroblasts derived from 14 normal subjects, the 2 obligate heterozygotes for MLS, and the patient was $145.2 \pm 4.6(82.7-178.7), 58.5(49.3-67.6)$, and 7.0, respectively. Occasional overlap between normal subjects and heterozygotes again occurred with single enzyme determinations, but there was no overlap between the mean values of replicate assays performed on each case. Sibling $I$ and sibling 2 showed activity of 51.0 and 96.0, respectively, confirming the leukocytes. Arylsulfatase $B$ activity in cultured skin fibroblasts of 11 patients with 7 other inborn errors of metabolism, including patients with Hurler's syndrome, Hunter's syndrome, and metachromatic leukodystrophy was within normal range. The lysosomal enzymes arylsulfatase $A$ (EC. 3.1.6.1), $\alpha$-D-galatosidase (EC. 3.2.1.22), $\alpha$-glucosidase (EC. 3.2.1.20), $\alpha$ L-iduronidase (EC. 3.2.1.76), $\alpha$-D-mannosidase (EC. 3.2.1.24), $\alpha$-L-fucosidase (EC. 3.2.1.51), $\beta$-D-galactosidase (EC. 3.2.1.23),
$\beta$-D-glucosidase (EC. 3.2.1.21), and $\beta$-D-glucuronidase (EC. 3.2.1.31) were normal in cultured skin fibroblasts of the patient with MLS. No arylsulfatase $B$ activity was detected in a long term lymphoid cell line established from the patient with MLS. The arylsulfatase $B$ activity in 10 normal lymphoid cell lines was $25.2 \pm 5.6$ with a range of 15.8-31.8. In cultured amniotic fluid cells from 10 normal pregnancies the arylsulfatase $B$ activity was $203.2 \pm 49.9$, with a range of 136.3-302.7. The findings indicate that peripheral leukocytes, cultured skin fibroblasts, and long term lymphoid cell lines can be used for the diagnosis of MLS, and that carrier detection is possible. Also the finding of arylsulfatase $B$ activity in cultured amniotic fluid cells suggests that prenatal diagnosis of MLS is feasible.

\section{Speculation}

Deficiency of arylsulfatase $B$ is the basic metabolic defect in Maroteaux-Lamy syndrome. This enzyme probably catalyzes the cleavage of sulfate from the sulfated $\mathrm{N}$-acetylgalatosamine contained in dermatan sulfate. Its deficiency would result in tissue accumulation and urinary excretion of this mucopolysaccharide.

The Maroteaux-Lamy syndrome, first described in 1963 (16), is characterized by growth deficiency, coarse facies, corneal opacities, dysostosis multiplex, hepatosplenomegaly, cardiac valvular disease, normal or near normal intelligence, and an autosomal recessive mode of inheritance (17). There is increased urinary 